Canadian Science Publishing

Canadian Journal of Forest Research Revue canadienne de recherche forestière

\title{
Response of soil microbial communities to site preparation before afforestation
}

\begin{tabular}{|c|c|}
\hline Journal: & Canadian Journal of Forest Research \\
\hline Manuscript ID & cjfr-2017-0341.R2 \\
\hline Manuscript Type: & Article \\
\hline Date Submitted by the Author: & 21-Jan-2018 \\
\hline Complete List of Authors: & $\begin{array}{l}\text { Wang, Jianlei; Institute of Geographic Sciences and Natural Resources } \\
\text { Research, Chinese Academy of Sciences } \\
\text { Di, Yuebao; Institute of Geographic Sciences and Natural Resources } \\
\text { Research, Chinese Academy of Sciences, Qianyanzhou Ecological Research } \\
\text { Station, Key Laboratory of Ecosystem Network Observation and Modeling } \\
\text { Dai, Xiaoqin; Institute of Geographic Sciences and Natural Resources } \\
\text { Research Chinese Academy of Sciences, } \\
\text { Xu, Mingjie; Institute of Geographic Sciences and Natural Resources } \\
\text { Research, Chinese Academy of Sciences } \\
\text { Fu, Xiaoli; Institute of Geographic Sciences and Natural Resources } \\
\text { Research, Chinese Academy of Sciences, } \\
\text { Wang, HuiMin; Qianyanzhou Ecological Station, } \\
\text { Wang, Yidong; Tianjin Normal University, Tianjin Key Laboratory of Water } \\
\text { Resources and Environment }\end{array}$ \\
\hline Keyword: & $\begin{array}{l}\text { Brush clearing, Controlled burning, Overall soil preparation, Spot soil } \\
\text { preparation, Subtropical China }\end{array}$ \\
\hline $\begin{array}{r}\text { Is the invited manuscript for } \\
\text { consideration in a Special } \\
\text { Issue? : }\end{array}$ & N/A \\
\hline
\end{tabular}




\section{Response of soil microbial communities to site preparation before 2 afforestation}

3 Jianlei Wang ${ }^{1,2,7}$, Yuebao $\mathrm{Di}^{1,2,7}$, Xiaoqin Dai ${ }^{1,2,3}$, Mingjie $\mathrm{Xu}^{1,4}$, Xiaoli $\mathrm{Fu}^{1,2,3,{ }^{*}}$, Huimin Wang ${ }^{1,2,3,{ }^{*}}$, $4 \quad$ Yidong Wang 5,6

$5{ }^{1}$ Qianyanzhou Ecological Research Station, Key Laboratory of Ecosystem Network Observation 6 and Modeling, Institute of Geographic Sciences and Natural Resources Research, Chinese

7 Academy of Sciences, Beijing 100101, China

$8{ }^{2}$ College of Resources and Environment, University of Chinese Academy of Sciences, Beijing, 9 100190, China

$10{ }^{3}$ Jiangxi Key Laboratory of Ecosystem Processes and Information, Ji'an, 343725, China

$11{ }^{4}$ College of Agronomy, Shenyang Agricultural University, Shenyang, 110866, China

$12{ }^{5}$ Tianjin Key Laboratory of Water Resources and Environment, Tianjin Normal University, 13 Tianjin, 300387, China

$14{ }^{6}$ Tianjin Key Laboratory of Environmental Change and Ecological Restoration, School of 15 Geographic and Environmental Sciences, Tianjin Normal University, Tianjin, 300387, China

$16 \quad{ }^{7}$ These authors contributed equally to this work

* Corresponding author: Institute of Geographic Sciences and Natural Resources Research, No. 11A, Datun Road, Chaoyang District, Beijing 100101, China. Tel: +86 10 64889913; Fax: +86 10 64889913. 
22

\section{Abstract:}

Site preparation is a common practice before afforestation, which can increase soil carbon (C) release by changing the soil microbial community. This study examined changes in soil microbial communities at two different times (the $7^{\text {th }}$ and $98^{\text {th }}$ days, D7 and D98) after site clearing (brush clearing vs. controlled burning), followed by soil preparation (overall soil preparation, OP; spot soil preparation, SP; and no soil preparation, NP). Results showed that the total, bacterial, fungal, and actinomycetic phospholipid fatty acids (PLFAs) in controlled burning plots increased compared to that in the brush clearing plots at the two sampling times. Within brush clearing plots, OP significantly reduced the total, bacterial, fungal, and actinomycetic PLFAs, whereas SP showed a significant increase in these groups in comparison to NP. In addition, soil microbial community showed obvious seasonal variation in brush clearing plots. Within controlled burning plots, OP significantly decreased the total, bacterial, fungal, and actinomycetic PLFAs. The variations in microbial community composition significantly correlated with soil organic $C$, total nitrogen $(\mathrm{N})$, dissolved organic $\mathrm{C}$ and $\mathrm{C}: \mathrm{N}$ ratios. Our results suggest that controlled burning and spot soil preparation can create some soil condition more conducive to soil microbial communities in short-term, but the long-term effects merit further investigation.

Keywords Brush clearing; Controlled burning; Overall soil preparation; Spot soil preparation; Subtropical China 
China has the largest forest plantation area in the world, which is approximately 69.33 million ha, based on the most recent national $8^{\text {th }}$ forest inventory. The plantations play an increasingly important role in forest carbon sequestration and mitigation of $\mathrm{CO}_{2}$ emission (Huang et al. 2007). However, some studies have indicated that plantations do not increase the soil $\mathrm{C}$ at their initial stage (Kaye et al. 2000; Huang et al. 2009). This may occur because the site preparation before afforestation increases the soil $\mathrm{C}$ release (Wang et al. 2016). The rapid increase in microbial activity following site preparation is inherent in determining the $C$ release (Schmidt et al. 2011). On the other hand, soil microbial activity also influences the soil nutrient cycling, which may directly or indirectly influence the plant productivity and C sequestration (Van Der Heijden et al. 2008). Therefore, a complete understanding of the soil microbial dynamics would help explain the variation in soil $\mathrm{C}$ release and predict plant productivity after site preparation.

In order to improve the survival and growth of planted trees, site preparation is a common silvicultural practice before planting. Generally, site preparation includes site clearing and soil preparation; in which site clearing can be further divided into brush clearing and controlled burning, while soil preparation can be divided into overall soil preparation and spot soil preparation (Wang et al. 2016). Site preparation removes or inverts the forest floor materials, causing changes in bulk density, moisture, and thermal characteristics of mineral soils (Van Der Heijden et al. 2008). Such changes may further affect soil microbial community composition. Brush clearing has been 
shown to reduce the abundance of soil fungi (Bååth 1980), bacteria, and actinomycetes (Haque et al. 2012), due to a decline in soil $\mathrm{C}$ availability induced by the cessation of root growth and exudation. However, the remaining detritus after brush clearing may increase nutrient availability and improve the abundance of soil microorganisms in the short-term (Harmon et al. 2009). Controlled burning may affect soil microorganisms via both direct and indirect mechanisms (Dooley and Treseder 2012). High temperature during controlled burning may lead to heat-induced microbial mortality (Hart et al. 2005). In addition, controlled burning may alter the soil microbial community composition due to the differences in microbial sensitivity to temperature (Cairney and Bastias 2007). Controlled burning also alters soil physicochemical properties, such as soil temperature, moisture and nutrients (Certini 2005). These changes may have positive or negative consequences for microbes (Peay et al. 2009; Dooley and Treseder 2012). Although numerous studies have measured the changes in soil microbial community following brush clearing and controlled burning, the results are inconsistent.

Soil preparation is a combination of plowing and raking. Overall soil preparation and spot soil preparation refer to soil preparation that cover the total area and only parts of the area, respectively. Soil preparation mixing organic materials with mineral soils may stimulate microbial growth and a shift in the microbial community structure, due to the improved soil aeration and substrate quality (Mallik and Hu 1997). For example, aerobic microorganisms may become dominant in these plots because soil preparation decreases the soil moisture and bulk density but promotes the diffusion of 
oxygen (Mathew et al. 2012). Although many studies have investigated the effects of soil preparation on soil microbial communities, the impact of soil preparation intensity on the soil microbial community structure is not well understood. In addition, soil preparation following site clearing would result in the mixing of detritus or ash with mineral soil, which may have interactive effects on soil microbial communities. Phospholipid fatty acids (PLFAs) analysis is a method to examine the soil microbial community composition, and the phospholipids are rapidly degraded following cell death. Therefore, PLFAs are a reliable indicator of living microorganisms (Bardgett et al. 1999). The main objective of the present study was to assess the effects of different site preparations on soil microbial communities in subtropical China. We hypothesized that (1) compared with brush clearing, controlled burning would increase the PLFAs abundance in the short-term by alleviating nutrient limitations, but decrease the fungal PLFAs, as fungi are more heat sensitive than bacteria, (2) the PLFAs abundance would increase after soil preparation due to the increase in the amount of bioavailable substances after the mixing of the organic and mineral layers, and (3) site preparation would affect the seasonal variation in soil microbial community composition.

\section{Materials and methods}

\subsection{Study area}

The experimental site is located at the Qianyanzhou Ecological Research Station $\left(26^{\circ} 44^{\prime} 39^{\prime \prime} \mathrm{N}, 115^{\circ} 03^{\prime} 33^{\prime \prime} \mathrm{E}\right)$ in subtropical China. The climate is a typical subtropical 
107

108

monsoon with a significant seasonal air temperature variation and an uneven distribution of rainfall. The mean annual temperature is $17.9^{\circ} \mathrm{C}$ and the precipitation is $1485 \mathrm{~mm}$. The temperature and precipitation of the experiment period are shown in Fig. S1. The soil is classified as Ultisols according to the World Reference Base Soil Taxonomy (1998). The plots were laid out on an abandoned orange orchard, which had a slope of less than $5^{\circ}$. The vegetation of the plots was dominated by Cogon grass (Imperata cylindrica (Linn.) Beauv.) and Canadian fleabane (Conyza canadensis (L.) Cronq.). Additional information about the soil physicochemical and microbial community properties are provided in Table S1.

\subsection{Experimental design}

A split-plot design was used for this experiment. The type of site clearing, i.e., brush clearing (BC) and controlled burning (CB), make up the primary treatment, while soil preparation, i.e., overall soil preparation (OP), spot soil preparation (SP), and no soil preparation (NP), comprise the secondary treatment (Fig. S2), thus six treatments were established. There were three pairs of $14 \mathrm{~m} \times 9 \mathrm{~m}$ (each pair formed a block). In each pair, plants growing in the plots were removed by brush clearing and controlled burning, respectively. The brush clearing or controlled burning plots were divided into three $4 \mathrm{~m} \times 4 \mathrm{~m}$ subplots and then treated with overall soil preparation, spot soil preparation (four spots in each subplot, each spot was distributed approximately $2 \mathrm{~m}$ apart with size of $50 \mathrm{~cm} \times 50 \mathrm{~cm} \times 40 \mathrm{~cm}($ Length $\times$ Width $\times$ Depth) $)$ or no soil preparation. Further details of the site preparations are listed in Table S2. 
128

129

130

131

132

133

134

135

136

137

\subsection{Soil sampling and analysis}

Site preparation was undertaken on 24 March 2011. After 7 and 98 days of site preparation (D7 and D98), surface $(0-10 \mathrm{~cm})$ soil samples were collected after removing the litter and organic horizon. In NP and OP, five soil samples from two diagonal lines through each plot were collected and pooled in one composite sample. In SP, we collected soil samples from the center of the spots. A total of 36 soil samples (two sampling times) were collected for analyzing the soil physicochemical properties and the microbial community composition. Soil samples were divided into two parts after being passed through a 2-mm sieve. One was used to determine the total organic carbon (TOC), total nitrogen (TN), dissolved organic carbon (DOC) and $\mathrm{pH}$. The other was stored at $-20^{\circ} \mathrm{C}$ until microbial community analysis. The soil bulk densities were measured using ringer samplers. The TOC and TN contents were measured using the CN-element analyzer (Elementar Vario Max CN, Mt. Laurel, NJ).

The DOC was extracted with $0.5 \mathrm{~mol} \mathrm{~L}^{-1} \mathrm{~K}_{2} \mathrm{SO}_{4}$ solution, and determined by a total organic carbon analyzer (Shimadzu TOC-5050A, Kyoto, Japan). The pH was measured potentiometrically in soil-water suspension (soil:water, 1:2.5).

The microbial community composition was determined by PLFAs analysis. Before the PLFAs extraction, soil moisture was measured using gravimetric methods and then measured after drying to a constant weight at $105^{\circ} \mathrm{C}$. The PLFAs profile was determined for each sample by extraction as described by Sun et al. (2011). Fatty acids were expressed in nmol $\mathrm{g}^{-1}$ dry soil. Bacteria were represented by the PLFAs

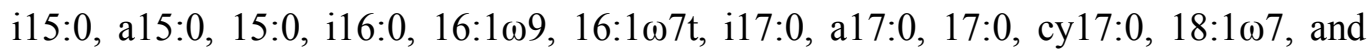


150

151

152

153

154

155

156

157

158

159

160

161

162

163

164

165

166

167

cy19:0, fungi were represented by $18: 2 \omega 6,9$, and 18:1 $\omega 9$, and actinomycetes were represented by 10Me16:0, 10Me17:0, and 10:Me18:0 (Bossio and Scow 1998; Frostegård and Bååth 1996; Frostegård et al. 2011; Sun et al. 2011).

\subsection{Statistical analysis}

We used nested analysis of variance (ANOVA) to test the effects of site clearing and soil preparation, as well as their interactions on soil physicochemical properties and soil microbial community using SPSS Version 16.0 (SPSSInc., Chicago, Illinois, USA). The treatments were set as between-subject factors, and the measurement dates were selected as within-subjects variable. Principal component analysis (PCA) was performed to evaluate the changes in the microbial community composition under different site preparation treatments using CANOCO 4.5 (Ithaca, NY, USA). Redundancy analysis was used to determine which factors were related to the variation in the soil microbial community composition among the various experimental treatments. The significance of the RDA results was tested by a permutation test (999 permutations). Statistically significant differences were identified at $P<0.05$.

\section{Results}

\subsection{Responses of soil microbial community to site preparation}

168 Significant effects of site preparation on soil microorganisms were identified (Fig. 1 169 and Table 1). Compared with brush clearing (NP), controlled burning (NP) 
170

171

172

173

174

significantly increased the total PLFAs (totPLFAs), bacterial PLFAs (bacPLFAs), fungal PLFAs (funPLFAs), and actinomycic PLFAs (actPLFAs), on average (based on two sampling times), by $44 \%, 54 \%, 33 \%$, and $57 \%$, respectively. Furthermore, controlled burning significantly reduced the funPLFAs:bacPLFAs ratio by $16 \%$ at $\mathrm{D} 7$. Soil preparation also significantly affected the soil microbial community. Within brushing clearing plots, over two sampling times, OP significantly decreased the totPLFAs (33.5\%), bacPLFAs (33.3\%), funPLFAs (39.9\%), and actPLFAs (43.9\%), whereas SP significantly increased them by $26.0 \%, 27.8 \%, 26.8 \%$, and $35.2 \%$, respectively, compared with NP. Within controlled burning plots, much lower values of totPLFAs, bacPLFAs, funPLFAs and actPLFAs were observed in OP. Compared with NP, on an average, they were decreased by $67.5 \%, 69.1 \% 74.0 \%$, and $70.9 \%$, respectively. In contrast, SP significantly increased them by $26.0 \%, 27.8 \%, 26.8 \%$, and $35.2 \%$, respectively.

Sampling times significantly affected the soil microbial community (Table 1). Across the 18 plots, totPLFAs, bacPLFAs, funPLFAs, and actPLFAs, were $15 \%, 14 \%$, $17 \%$, and $34 \%$ higher at $\mathrm{D} 7$ than those at $\mathrm{D} 98$, respectively. In addition, the results also revealed significant interactive effects of site clearing and sampling time on soil microbial community (Table 1). For example, totPLFAs was significantly decreased by $29.8 \%$ at D98 than that at D7 in brush clearing plots (NP). However, it was only decreased slightly (10.1\%) in the controlled burning plots (NP).

\subsection{Main factors affecting soil microbial community}


191

192

Principal component analysis (PCA) of the PLFAs data showed that the shift in microbial community composition was due to the site preparation treatment and the sampling time (Fig. 2). PC1 explained 72.1\% (D7, Fig. 2a) and 50.3\% (D98, Fig. 2b) of the variation and discriminated OP from NP and SP (along PC1, $P<0.01$ from ANOVA). OP was clustered to the right, and SP and NP to the left of the origin. Specifically, OP was more abundant in i14:0, i17:0, and i18:0, whereas SP and NP were more abundant in $16: 1 w 5 c, 18: 1 w 7 c, 18: 1 w 9 c$, and cy19:0. PC2 separated the $\mathrm{BC}$ from the $\mathrm{CB}$, but accounted for only $7.8 \%$ of the variation at $\mathrm{D} 7$ (along $\mathrm{PC} 2, \mathrm{P}<$ 0.01 from ANOVA). Higher values in the BC along PC2 were the 16:0 and i18:0, while the CB primarily composed of 15:0, i15:0, and a17:0. By contrast, there were no major differences in the microbial community composition between $\mathrm{BC}$ and $\mathrm{CB}$ plots at D98.

\subsection{Correlations between microbial community and soil properties}

The site preparation significantly affected the soil physicochemical properties, especially after soil preparation (Table 2 and Table S3). Redundancy analysis (RDA) revealed that soil physicochemical properties have significant effects on soil microbial community composition (Fig. 3). Soil physicochemical properties explained $64.9 \%$ and $64.1 \%$ of the variation in soil microbial community structure at D7 and D98, respectively. The first axis (RD1) explained 53.9\% (Fig. 3a) and 40.0\% (Fig. 3b) of the total variance in the PLFA profiles and was most strongly correlated with TOC, C/N, DOC and TN (Table S3). The second axis (RD2) accounted for only 5.4\% and 
212

213

214

215

216

217

$15.5 \%$ of the variance at $\mathrm{D} 7$ and $\mathrm{D} 98$, respectively.

To better understand how each soil property variable influenced the soil microbial community structure, variation partitioning analysis (VPA) was performed using the selected variables. Three important soil properties (TOC, TN and DOC) were selected by the BioEnv procedure and variance inflation factor (VIF) in cluster-cluster aggregation (CCA) model. A total of 37.2\% (D7) and 41.4\% (D98) variation in the microbial communities could be explained by the three soil properties and their interactions. In D7, TOC was able to independently explain $14.6 \%$ of the variation, whereas TN explained $7.3 \%$, and DOC explained $10.7 \%$ of the variation. In D98, TOC, TN, and DOC independently explained $14.3 \%, 6.1 \%$, and $14.2 \%$ of the variation, respectively. These results suggest that the variables of DOC over time appeared to have more influence in shaping the microbial community functional structures.

\section{Discussion}

\subsection{Site clearing effects on the microbial community composition}

Compared with brush clearing, controlled burning significantly increased the soil microbial PLFAs abundance and altered the microbial community structure. These results support our first hypothesis, and are consistent with the results of Rutigliano et al. (2007) and Okonkwo (2010), but are inconsistent with those of Dooley and Treseder (2012) and Wang et al. (2012). Differential responses in the microbial community to controlled burning could be related to the differences in the burning 
intensity. Pourreza et al. (2014) observed a significant decrease in soil microbial biomass (assessed by substrate-induced respiration method) in high severity burning, but not in low severity burning. In our experiment, large shrubs were removed, and the controlled burning generally lasted for less than 20 minutes. Therefore, the direct effect of burning heat on microorganisms may not be too serious. In addition, the changes in soil properties after controlled burning may increase the soil microbial biomass. Bárcenas-Moreno et al. (2011) found that large amounts of DOC were released, and Wan et al. (2001) found the soil inorganic nitrogen increased immediately after burning. These pulse of soil nutrients could stimulate the growth of surviving microorganisms. However, in our study, we lack the measurements for soil inorganic nitrogen, but we found that the DOC significantly increased by $40.0 \%$ immediately after controlled burning. Furthermore, controlled burning may change the soil microclimate. Previous studies have concluded that burning increases the soil temperature and decreases the soil moisture (Neary et al. 1999; Kim and Tanaka 2003). In the present study, compared with brush clearing plots, controlled burning had no significant effects on soil temperature, but it significantly decreased the soil moisture by $14.1 \%$ and $9.8 \%$ at $\mathrm{D} 7$ and $\mathrm{D} 98$, respectively. In this region, the rainfall occurred mainly (approximately 60\%) from March to June (Wang et al. 2012), and thus, this excess precipitation might have limited the microbial growth. Therefore, the differences in DOC and soil moisture might help explain the differences between two site clearing methods.

In our study, the funPLFAs:bacPLFAs ratio was lower in controlled burning plots 
than in brush clearing plots. Many previous studies have noted that fungi may be more severely affected by burning, as they are more sensitive to heat than bacteria (Dooley and Treseder 2012). However, compared with brush clearing, there was no significant effect in funPLFAs, but the bacPLFAs was significantly increased in controlled burning. It is assumed that changes in soil physical-chemical properties after controlled burning may favor the growth of bacteria. Bárcenas-Moreno et al. (2011) found that fungi are the dominant species in the soils with low $\mathrm{pH}$, as they are more tolerant towards acidic soils. However, ash deposition followed by controlled burning increases the soil $\mathrm{pH}$, which may favor the growth of bacteria (Okonkwo 2010). In addition, once the bacteria recolonize the soil substrate, they could exhibit an antagonistic effect on fungal growth (Bárcenas-Moreno and Bååth 2009). In this study, we found that soil $\mathrm{pH}$ was slightly increased after controlled burning, which could favor an increase in bacterial activity, while negatively affecting fungal growth.

\subsection{Soil preparation effects on the microbial community composition}

OP significantly decreased the abundance of PLFAs at the two sampling times. These results are inconsistent with the second hypothesis and could be explained by the followings. First, the soil preparation could directly affect the soil microorganisms. For example, some groups of organisms, such as mycorrhizal fungi, are reduced by the disruption of their hyphal networks (van der Heyde et al. 2017). In addition, soil preparation could also directly affect soil microorganisms by altering the soil layers, as the microbial biomass is concentrated in surface soils (Taylor et al. 2002). Second, 
site preparation could also indirectly affect the soil microbial community by changing the soil physicochemical properties (Dooley and Treseder 2012). In the same regions, Gao et al. (2015) investigated the soil C, N, and P content for six different land use types in the same region, and found that they all declined with increasing soil depth. Soil preparation may homogenize the soil nutrients and stimulate the microbial growth of subsoil. However, in this study, we just investigated the soil PLFAs abundance in the surface soil $(0-10 \mathrm{~cm})$, and found that OP significantly decreased them as well as the soil nutrients. The RDA results also indicated that the microbial community structures were correlated with the TOC, C/N, TN, and DOC (Fig. 3). In contrast with OP, SP increased the abundance of PLFAs. This result indicated that the soil preparation intensity is an important factor that affects the composition of soil microbial community. Compared with NP, SP had no significant effects on TOC, TN and DOC, which ensured an adequate nutrient supply for soil microorganisms. In addition, the surrounding no soil preparation patches might have acted as a biotic source for microbial re-colonization.

A lower funPLFAs:bacPLFAs ratio was observed after OP on D7 (Fig. 1). The change in the microbial community structure following site preparation suggests that microbial species are differentially affected by disturbances and that fungi are more sensitive to disturbance than bacteria. In OP, the treatments would disrupt the hyphal networks of fungi, resulting in a decrease in the fungal biomass (Achatz et al. 2013). As fungi typically exhibit a hyphal growth form, the hyphal network could transfer the nutrients and resources to the sites where they are limiting (Frey et al. 2003). In 
contrast, bacteria are present as individual cells, so soil preparation has a lesser impact on soil bacteria. SP had no effect on the funPLFAs:bacPLFAs ratio, because it created a mosaic of heterogeneous patches, wherein the fungal hyphae could explore a large soil volume and rapidly build up their hyphal networks (Herman et al. 2012). Thus, it is reasonable to expect that fungal hyphae can explore spots and rapidly recolonize.

\subsection{Temporal variation in the soil community composition}

Sampling time had a significant effect on the soil microbial community composition (Table 3). Compared with D7, the average PLFA abundances (among the six site preparation methods) were lower at D98. These results were consistent with those of Stres et al. (2008), who observed a slight increase in microbial biomass under wet and cold conditions (March and May). The soil temperature positively correlates with soil microbial activity. However, soil microbial biomass (measured by substrate-induced respiration) was higher in the soil exposed to cold than to warm conditions (Stres et al. 2008). The soil moisture was an important driver of microbial activity, and the high or low soil moisture would decrease microbial activity by reducing oxygen diffusion or soluble substrate diffusion. Dong et al. (2015) found that the soil moisture strongly limited the soil PLFA abundance in Chinese fir in the same area. In this study, soil temperature increased from March to June, and strong temporal fluctuations in soil moisture were observed (Fig. S4). On an average, the soil temperature was $10.34{ }^{\circ} \mathrm{C}$ higher, whereas the soil moisture was $21.31 \%$ lower at D98 than at D7. Therefore, it is not surprising that season had a large effect on microbial 
community structure.

Other studies have found that the differences in microbial community between sampling dates on the seasonal basis in change carbon availability (Griffiths et al. 2003; Rasche et al. 2011). Griffiths et al. (2003) has showed that seasonal changes in microbial activity and biomass correlate with increases in $\mathrm{C}$ source availability from root exudation. However, in order to exclude the effects that may arise from plants, no tree was planted after site preparation in the present study. Therefore, there was little $\mathrm{C}$ input through litter and root exudates, and the microbial growth was considered to be limited by $\mathrm{C}$ availability. However, the decreases in PLFA abundances were found only in the brush clearing plots. The abundance of total microbes, bacteria, fungi and actinomycetes, on average (based on three soil preparation methods), were $29.1 \%$, $28.9 \%, 25.9 \%$, and $29.5 \%$ lower at D98 than at D7, respectively. In contrast, sampling time had no effect on the controlled burning plots. Compared with brush clearing, an immediate increase in DOC and other nutrients was found after controlled burning, which could stimulate the microbial growth. Bárcenas-Moreno et al. (2011) found that a large amount of DOC is released after burning, and that this increase lasts for 8 months and then decreases. Therefore, it is assumed that the improvement in nutrient availability after controlled burning can regulate the effects of seasonal weather changes on soil microorganisms in the experiment period.

\section{Conclusions}


339 This study demonstrated that, in short-term, different site preparations had

340 significantly different effects on soil microbial community composition, which varied

341 with the type and intensity of disturbance. Controlled burning stimulated the growth

342 of microorganisms, due to the increase in availability of inorganic nutrients by ash

343 deposition in short-term. Soil microorganisms were significantly increased by spot

344 soil preparation, but were significantly decreased by overall soil preparation. In

345 addition, these effects varied with the site clearing methods. Seasonal variation in

346 microbial community composition was observed in brush clearing plots, but not in

347 controlled burning plots. This could be attributed to the differences in soil

348 microclimate (soil moisture) and soil nutrients between brush clearing and controlled

349 burning. Long-term studies are needed to examine the responses of microbial

350 community to site preparation and their feedbacks to plant communities.

\section{Acknowledgments}

352 We thank S. Fu and L. Zhou for help with the PLFA analysis. This work was

353 financially supported by the National Natural Science Foundation of China (Project

354 No. 31070559; 31300381; 31500360), the NSFC Projects of International

355 Cooperation and Exchanges (31210103920), the Strategic Priority Research Program

356 of the Chinese Academy of Sciences: Carbon Budget and Relevant Issues

357 (XDA05070302), and the Gan-Po Distinguished Researcher Program.

\section{$358 \quad$ References}


359

360

361

362

363

364

365

366

367

368

369

370

371

372

373

374

375

376

377

378

379

Achatz, M., Rillig, M.C. 2013. Arbuscular mycorrhizal fungal hyphae enhance transport of the allelochemical juglone in natural soil. Hyphal mediated transport processes of the allelochemical juglone in soil, 48 .

Bååth, E. 1980. Soil fungal biomass after clear-cutting of a pine forest in central Sweden. Soil Biol. Biochem. 12: 495-500.

Bárcenas-Moreno, G., Bååth, E. 2009. Bacterial and fungal growth in soil heated at different temperatures to simulate a range of fire intensities. Soil Biol. Biochem. 41: $2517-2526$

Bárcenas-Moreno, G., García-Orenes, F., Mataix-Solera, J., Mataix-Beneyto, J., Bååth, E. 2011. Soil microbial recolonisation after a fire in a Mediterranean forest. Biol. Fertil. Soils 47: 261-272.

Bardgett, R.D., Mawdsley, J.L., Edwards, S., Hobbs, P.J., Rodwell, J.S., Davies, W.J. 1999. Plant species and nitrogen effects on soil biological properties of temperate upland grasslands. Funct. Ecol. 13: 650-660.

Bossio, D.A., Scow, K.M. 1998. Impacts of carbon and flooding on soil microbial communities: phospholipid fatty acid profiles and substrate utilization patterns. Microb. Ecol. 35: 265-278.

Cairney, J.W.G., Bastias, B.A. 2007. Influences of fire on forest soil fungal communities. Can. J. For. Res. 37:207-215.

Certini, G. 2005. Effects of fire on properties of forest soils: a review, Oecologia 143: $1-10$. 
Dong, W.Y., Zhang, X.Y., Liu, X.Y., Fu, X.L., Chen, F.S., Wang, H.M., Wen, X.F. 2015. Responses of soil microbial communities and enzyme activities to nitrogen and phosphorus additions in Chinese fir plantations of subtropical China. Biogeosciences, 12: 5537-5546.

Dooley, S.R., Treseder, K.K. 2012. The effect of fire on microbial biomass: a meta-analysis of field studies. Biogeochemistry 109: 49-61.

Drenovsky, R.E., Steenwerth, K.L., Jackson, L.E., Scow, K.M. 2010. Land use and climatic factors structure regional patterns in soil microbial communities. Glob. Ecol. Biogeogr. 19: 27-39.

Fernández, I., Cabaneiro, A., Carballas, T. 1997. Organic matter changes immediately after a wildfire in an Atlantic forest soil and comparison with laboratory soil heating. Soil Biol. Biochem. 29: 1-11.

Frey, S.D., Six, J., lliott, E.T. 2003. Reciprocal transfer of carbon and nitrogen by decomposer fungi at the soil-litter interface. Soil Biol. Biochem. 35: 1001-1004.

Frostegård, Å. Bååth, E. 1996. The use of phospholipid fatty acid analysis to estimate bacterial and fungal biomass in soil. Biol. Fert. Soil. 22: 59-65.

Frostegård, Å., Tunlid, A., Bååth, E. 2011. Use and misuse of PLFA measurements in soils. Soil Biol. Biochem. 43: 1621-1625.

Gao, Y., He, N., Yu, G., Chen, W., Wang, Q. 2014. Long-term effects of different land use types on $\mathrm{C}, \mathrm{N}$, and $\mathrm{P}$ stoichiometry and storage in subtropical ecosystems: A case study in China. Ecol. Engine. 67: 171-181. 
401

402

403

404

405

406

407

408

409

410

411

412

413

414

415

416

417

418

419

420

Haque, S.S., Ferdoshi, R., Miah, S., Anwar, M.N. 2012. Clear felling and burning effects on soil nitrogen transforming bacteria and actinomycetes population in Chittagong University campus, Bangladesh. J. For. Res. 23: 123-130.

Harmon, M.E. 2009. Woody detritus its contribution to carbon dynamics of old-growth forests: the temporal context. In Old-Growth Forests (pp. 159-190). Springer Berlin Heidelberg.

Hart, S.C., DeLuca, T.H., Newman, G.S., MacKenzie, M.D., Boyle, S.I. 2005. Post-fire vegetative dynamics as drivers of microbial community structure and function in forest soils. For. Ecol. Manage. 220: 166-184.

Herman, D.J., Firestone, M.K., Nuccio, E., Hodge, A. 2012. Interactions between an arbuscular mycorrhizal fungus and a soil microbial community mediating litter decomposition. FEMS Micro. Ecol. 80: 236-247.

Holden, S.R., Treseder, K.K. 2013. A meta-analysis of soil microbial biomass responses to forest disturbances. Front. Microbiol. 4.

Huang, M., Ji, J., Li, K., Liu, Y., Yang, F., Tao, B.O. 2007. The ecosystem carbon accumulation after conversion of grasslands to pine plantations in subtropical red soil of South China. Tellus B 59: 439-448.

Kaye, J.P., Resh, S.C., Kaye, M.W., Chimner, R.A. 2000. Nutrient and carbon dynamics in a replacement series of Eucalyptus and Albizia trees. Ecology 81: 3267-3273. 
421

422

423

424

425

426

427

428

429

430

431

432

433

434

435

436

437

438

439

440

441

442

Kim, Y., Tanaka, N. 2003. Effect of forest fire on the fluxes of $\mathrm{CO}_{2}, \mathrm{CH}_{4}$ and $\mathrm{N}_{2} \mathrm{O}$ in boreal forest soils, interior Alaska. Journal of Geophysical Research: Atmospheres, 108(D1).

Mallik, A.U., Hu, D. 1997. Soil respiration following site preparation treatments in boreal mixedwood forest. For. Ecol. Manage. 97: 265-275.

Mathew, R.P., Feng, Y., Githinji, L., Ankumah, R., Balkcom, K.S. 2012. Impact of no-tillage and conventional tillage systems on soil microbial communities. App. Environ. Soil Sci. 2012.

Neary, D.G., Klopatek, C.C., DeBano, L.F., Ffolliott, P.F. 1999. Fire effects on belowground sustainability: a review and synthesis. For. Ecol. Manage. 122: 51-71.

Okonkwo, C.I. 2010. Effect of burning and cultivation on soil properties and microbial population of four different land use systems in Abakaliki. Res. J. Agric. Biol. Sci. 6: 1007-1014.

Peay, K.G., Garbelotto, M., Bruns, T.D. 2009. Spore heat resistance plays an important role in disturbance-mediated assemblage shift of ectomycorrhizal fungi colonizing Pinus muricata seedlings. J. Ecol. 97: 537-547.

Pourreza, M., Hosseini, S.M., Sinegani, A.A.S., Matinizadeh, M., Dick, W.A. 2014. Soil microbial activity in response to fire severity in Zagros oak (Quercus brantii Lindl.) forests, Iran, after one year. Geoderma, 213: 95-102.

Rasche, F., Knapp, D., Kaiser, C., Koranda, M., Kitzler, B., Zechmeister-Boltenstern, S., Sessitsch, A. 2011. Seasonality and resource availability control bacterial and 
archaeal communities in soils of a temperate beech forest. The ISME journal, 5: 389-402.

Rutigliano, F.A., De Marco, A., D’Ascoli, R., Castaldi, S., Gentile, A., De Santo, A.V. 2007. Impact of fire on fungal abundance and microbial efficiency in C assimilation and mineralisation in a Mediterranean maquis soil. Biol. Fert. Soils 44: 377-381.

Schmidt, M.W.I., Torn, M.S., Abiven, S., Dittmar, T., Guggenberger, G., Janssens, I.a., Kleber, M., Kögel-Knabner, I, Lehmann, J., Manning, D.A.C., Nannipieri, P, Rasse, D.P., Weiner, S, Trumbore, S.E. 2011. Persistence of soil organic matter as an ecosystem property. Nature, 478: 49-56.

Stres, B., Danevčič, T., Pal, L., Fuka, M. M., Resman, L., Leskovec, S., Mandic-Mulec, I. 2008. Influence of temperature and soil water content on bacterial, archaeal and denitrifying microbial communities in drained fen grassland soil microcosms. FEMS Microbiol. Ecol. 66: 110-122.

Sun, Y., Wu, J., Shao, Y., Zhou, L., Mai, B., Lin, Y., Fu, S. 2011. Responses of soil microbial communities to prescribed burning in two paired vegetation sites in southern China. Ecol. Res. 26: 669-677.

Taylor, J.P., Wilson, B., Mills, M.S., Burns, R.G. 2002. Comparison of microbial numbers and enzymatic activities in surface soils and subsoils using various tetzniques. Soil Biol. Biochem. 34: 387-401.

Tomkins, I.B., Kellas, J.D., Tolhurst, K.G., Oswin, D.A. 1991. Effects of fire intensity on soil chemistry in a eucalypt forest. Soil Research, 29: 25-47. 
465 Van Der Heijden, M.G., Bardgett, R.D., Van Straalen, N.M. 2008. The unseen 466 majority: soil microbes as drivers of plant diversity and productivity in terrestrial 467 ecosystems. Ecol. Lett. 11: 296-310.

468 Van Der Heyde, M., Ohsowski, B., Abbott, L.K., Hart, M. 2017. Arbuscular 469 mycorrhizal fungus responses to disturbance are context-dependent. Mycorrhiza, $470 \quad 1-10$.

471 Wan, S., Hui, D., Luo, Y. 2001. Fire effects on nitrogen pools and dynamics in 472 terrestrial ecosystems: A meta-analysis. Ecol. Applic. 11: 1349-1365.

473 Wang, J., Wang, H., Fu, X., Xu, M., Wang, Y. 2016. Effects of site preparation 474 treatments before afforestation on soil carbon release. For. Ecol. Manage. 361: $475 \quad 277-285$.

476 Wang, Q., Zhong, M., Wang, S. 2012. A meta-analysis on the response of microbial 477 biomass, dissolved organic matter, respiration, and $\mathrm{N}$ mineralization in mineral $478 \quad$ soil to fire in forest ecosystems. For. Ecol. Manage. 271: 91-97. 
479 Table 1 Soil microbial variables in response to different site preparation methods. TotPLFAs, total 480 PLFAs; BacPLFAs, bacterial PLFAs; FunPLFAs, fungal PLFAs; ActPLFAs, actinomycetic PLFAs; 481 F: B ratios, fungal PLFAs:bacterial PLFAs ratios.

\begin{tabular}{|c|c|c|c|c|c|c|}
\hline Time & Treatments & $\begin{array}{l}\text { TotPLFAs } \\
\left(\mathrm{nmol} \mathrm{g}^{-1}\right)\end{array}$ & $\begin{array}{c}\text { BacPLFAs } \\
\left(\mathrm{nmol} \mathrm{g}^{-1}\right)\end{array}$ & $\begin{array}{l}\text { FunPLFAs } \\
\left(\mathrm{nmol} \mathrm{g}^{-1}\right)\end{array}$ & $\mathrm{F}: \mathrm{B}$ ratios & $\begin{array}{l}\text { ActPLFAs } \\
\left(\mathrm{nmol} \mathrm{g}^{-1}\right)\end{array}$ \\
\hline \multicolumn{2}{|c|}{ Site clearing $(\mathrm{C})$} & $* * *$ & $* * *$ & $\mathrm{~ns}$ & $* * *$ & $* *$ \\
\hline \multicolumn{2}{|c|}{ Soil preparation $(\mathrm{P})$} & $* * *$ & $* * *$ & $* * *$ & $* * *$ & $* *$ \\
\hline \multicolumn{2}{|c|}{ Sampling time $(\mathrm{T})$} & $* * *$ & $* *$ & $* *$ & ns & $* * *$ \\
\hline \multicolumn{2}{|r|}{$\mathrm{C} \times \mathrm{P}$} & $* * *$ & $* * *$ & $* * *$ & ns & $*$ \\
\hline \multicolumn{2}{|r|}{$\mathrm{C} \times \mathrm{T}$} & $* * *$ & $* *$ & $* *$ & ns & $*$ \\
\hline \multicolumn{2}{|c|}{$\mathrm{P} \times \mathrm{T}$} & ns & ns & $*$ & ns & $*$ \\
\hline \multicolumn{2}{|c|}{$\mathrm{C} \times \mathrm{P} \times \mathrm{T}$} & $\mathrm{ns}$ & ns & $\mathrm{ns}$ & ns & $* *$ \\
\hline
\end{tabular}


483 Table 2 Soil physicochemical properties as affected by the site preparation. TOC, soil total 484 organic carbon; TN, total nitrogen; BD, soil bulk density; DOC, dissolved organic carbon.

\begin{tabular}{lccccccc}
\hline \multicolumn{1}{c}{ Treatments } & $\begin{array}{c}\text { Moisture } \\
\left(\mathrm{cm}^{3} \mathrm{~cm}^{-3}\right)\end{array}$ & $\begin{array}{c}\mathrm{BD} \\
\left(\mathrm{g} \mathrm{cm}^{-3}\right)\end{array}$ & $\begin{array}{c}\mathrm{TOC} \\
\left(\mathrm{g} \mathrm{kg}^{-1}\right)\end{array}$ & $\begin{array}{c}\mathrm{TN} \\
\left(\mathrm{g} \mathrm{kg}^{-1}\right)\end{array}$ & $\begin{array}{c}\mathrm{C} / \mathrm{N} \\
\mathrm{nOC} \\
\left(\mathrm{mg} \mathrm{kg}^{-1}\right)\end{array}$ & $\mathrm{pH}$ \\
\hline Site clearing (C) & $\mathrm{ns}$ & $\mathrm{ns}$ & $\mathrm{ns}$ & $\mathrm{ns}$ & $* *$ & $\mathrm{~ns}$ & $\mathrm{~ns}$ \\
Soil preparation (P) & $* * *$ & $* * *$ & $* * *$ & $* * *$ & $* * *$ & $* * *$ & $\mathrm{~ns}$ \\
Sampling time (T) & $*$ & $* * *$ & $* * *$ & $* * *$ & $*$ & $\mathrm{~ns}$ & $*$ \\
$\mathrm{C} \times \mathrm{P}$ & $*$ & $\mathrm{~ns}$ & $* *$ & $\mathrm{~ns}$ & $* *$ & $\mathrm{~ns}$ & $\mathrm{~ns}$ \\
$\mathrm{C} \times \mathrm{T}$ & $\mathrm{ns}$ & $* *$ & $\mathrm{~ns}$ & $*$ & $\mathrm{~ns}$ & $*$ & $\mathrm{~ns}$ \\
$\mathrm{P} \times \mathrm{T}$ & $* * *$ & $\mathrm{~ns}$ & $\mathrm{~ns}$ & $\mathrm{~ns}$ & $\mathrm{~ns}$ & $\mathrm{~ns}$ & $*$ \\
$\mathrm{C} \times \mathrm{P} \times \mathrm{T}$ & $\mathrm{ns}$ & $* *$ & $\mathrm{~ns}$ & $\mathrm{~ns}$ & $\mathrm{~ns}$ & $\mathrm{~ns}$ & $\mathrm{~ns}$ \\
\hline
\end{tabular}


486 Fig. 1 Responses of the soil microbial PLFAs to the site preparation. The bar represents standard

487 error. Different letters indicate significant differences among the three soil preparation methods

488 within brush clearing and controlled burning plots $(P<0.05)$.

489 Fig. 2 Principal component analyses (PCA) of PLFAs under different site preparation treatments

490 (a, D7; b, D98). The open circle, square and triangle represent the no, overall, and spot soil

491 preparation after brush clearing, while the closed circle, square and triangle represent the no,

492 overall, and spot soil preparation after controlled burning, respectively.

493 Fig. 3 Redundancy analyses (RDA) of the soil microbial community composition under different

494 types of site preparation (a, D7; b, D98). Vectors represent environmental variables. TOC, total

495 organic carbon; TN, total nitrogen; $\mathrm{C} / \mathrm{N}, \mathrm{C}: \mathrm{N}$ ratio; $\mathrm{M}$, soil moisture; $\mathrm{BD}$, soil bulk density; DOC,

496 dissolved organic carbon. The open circle, square and triangle represent no, overall and spot soil

497 preparation after brush clearing, while the closed circle, square and triangle represent no, overall

498 and spot soil preparation after controlled burning, respectively. 

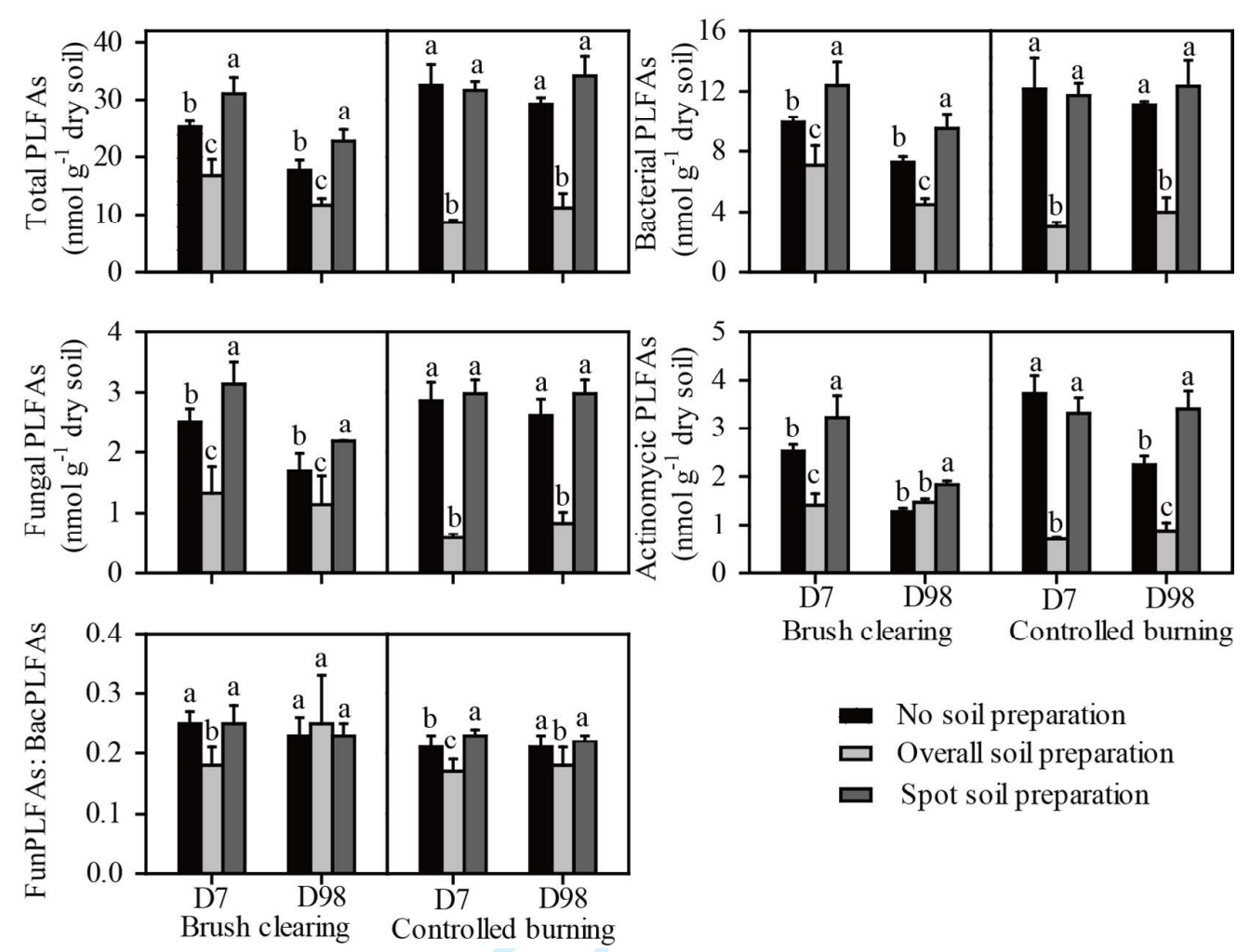

499

Fig. 1 

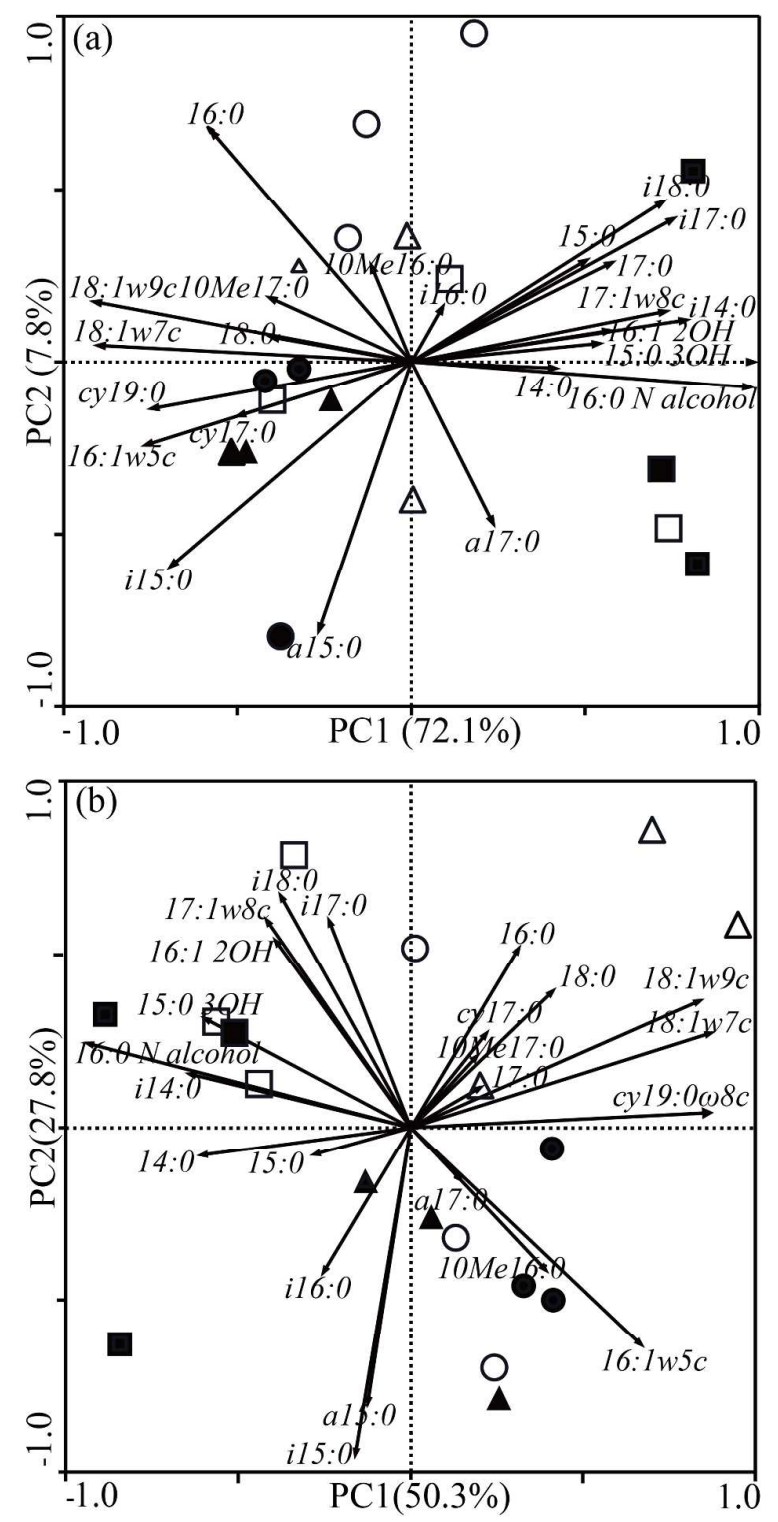

Fig. 2 

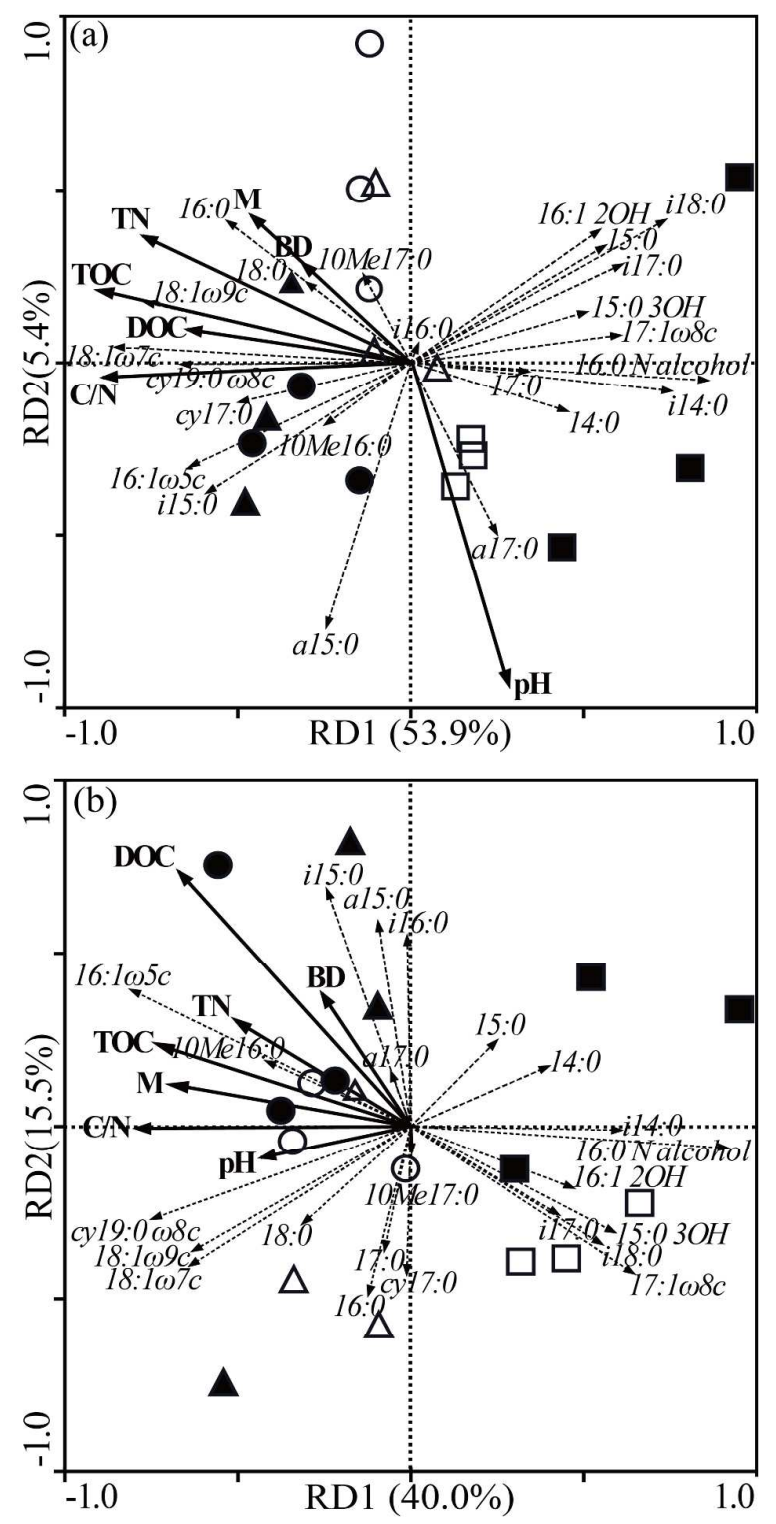

507 Fig. 3 